\title{
Guānxi Economics: Confucius Meets Lenin, Keynes, and Schumpeter in Contemporary China
}

\author{
Manfred Nitsch ${ }^{*}$ and Frank Diebel ${ }^{* *}$
}

The micro-foundations of the Chinese growth model are analysed within a comprehensive monetary theory of economic development, based on Schumpeter, Keynes, and the contemporary monetary Keynesians. The Confucian traditions and the Leninist party power structure are identified as the main specific traits of the social formation in contemporary China. In the capitalist mode of production, money sets the stage, and the interplay between private creditors and debtors is bundled into a coherent, dynamic whole by the central bank in the economic sphere and by more or less democratic institutions in the political arena. Combining the reproductive, care-taking traits of socialism with the entrepreneurial dynamism of private property and, above all, with the design and enforcement of overall social and economic coherence through the "vanguard" Communist Party makes an unique and ingenious institutional Chinese set-up. The constitutive character of Guânxi - the magic word for trust, confidence, reliability, righteousness, mutual benefit and cosmic order - for the working of the whole Chinese economic system is identified and described.

JEL classifications: DoI, EI2, OI6, P26

Keywords: China, Chinese Communist Party, economic growth, transitional economy, mode of production

* Department of Economics and Business Administration and University Center Latin American Institute, Free University Berlin.

** Berlin School of Economics.

Correspondence Address:

Frank Diebel, Berlin School of Economics, Badensche Straße 50-5I, I0825 Berlin, Germany, e-mail: china@frankdiebel.de

Received 30 Mar 2007, accepted 24 Jan 2008

(C) INTERVENTION 5 (I), 2008, 77-IO4 


\section{The Challenge}

The recent economic growth story of the People's Republic of China is not yet fully understood. Consequently, the amazing increase in national income over the past 25 years is still a matter of debate among economic theorists. Recent research has shed some light on the macro-economics of economic growth in China, concentrating on the export drive via an undervaluation of its currency (Priewe 2005, Herr 2002). In this paper, the micro-foundations of the Chinese growth model are analysed, much in the same vein as Priewe (2005) and Herr (2002), namely within a comprehensive monetary theory of economic development, based on Schumpeter, Keynes, and the contemporary monetary Keynesians such as Hajo Riese, but adapted to the Confucian traditions and the contemporary Leninist party power structure in China.

The benefit of a Monetary Theory of Development and Underdevelopment in contrast to other theories of economic growth is that it does not take growth for granted but encompasses also stagnation and underdevelopment, emphasising the social division of labour and in particular the institutional set-up of the monetary sphere. Instead of referring to time-preference for future consumption, "animal spirits", and mechanical incremental capital-output ratios, with secure private property rights, a rule of law, and the vector of real resources as the dominant budget constraint, as in neoclassical theory, money, in a very broad sense of the term, is considered here to be dominant in any contemporary economy, so that macro as well as micro financial issues become crucial variables, from crashes and hyperinflation crises to mercantilistic reserve accumulation strategies. All the more, a phenomenon like spectacular growth in China, where many of the much-invoked "preconditions " of development in a functioning capitalist market economy are conspicuously absent, presents a formidable challenge to economic theory-building, particularly for developing and transition countries. In the following section, the Schumpeter-Keynesian growth model is sketched out, with a view on whether and how it could be applied to contemporary China, whose basic economic structure is briefly characterised in section 3. In stark contrast to the transition path of Russia and other formerly socialist economies, a loss of coherence could be avoided due to the perseverance of the Communist Party. Finally, scenarios for future developments and some theoretical lessons learned conclude the paper.

\section{Schumpeter's Accumulation Model for Monetary Economies}

As the main visualising instrument for explaining, step by step, the implicit growth model of Joseph Schumpeter's theory of economic development (I9I2/34), the balance sheets of the economic agents involved are used, which consist of stocks (not flows) with assets on the left hand side, and liabilities on the right, showing net wealth or equity as a balance. Our agents in focus are the entrepreneur (ER), the banker (BK), the wealth owner (WO), the employed worker or employee (LE), the unemployed labourer (LU), and the consumer (CO). The State (ST) is only the night-watchman and rule-setter. In the begin- 
ning, money is one of the assets in the portfolio of all the actors (see figure $\mathrm{I}$ ), who use it as cash in spot markets so that its real, not its nominal value counts within the preference scale of the individuals.

\section{Figure I: Money as Cash Asset - Friedman's Helicopter and Neoclassical Savings-first Growth Theory}
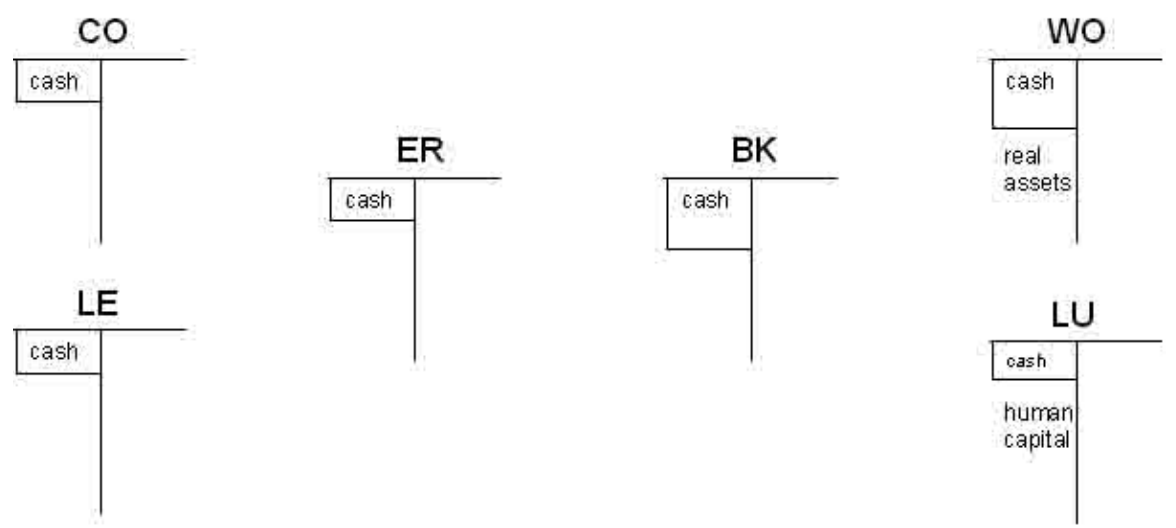

When Milton Friedman's famous helicopter throws down the same amount of cash, and each individual gathers exactly the same amount which he or she $\mathrm{e}^{\mathrm{I}}$ already is holding in their portfolios, prices rise and double, but nothing else happens with the real economy (Friedman 1992: ch. 2). Economic growth is essentially an accumulation of real assets, financed out of the savings of the same or some other individual household or enterprise which, in turn, are determined by the time preference for future consumption.

In essence, this thinking is reflected not only in the more elaborate theories of monetarists with regard to monetary policies, but also in neoclassical growth theories where, on the national level, investment (I) is determined by the national savings rate $(S)$, and if that is insufficient to finance an intended growth objective, the "savings gap « has to be filled with foreign savings, namely a current account deficit $(\mathrm{M}-\mathrm{X})$, be it commercial debt, foreign direct investment, remittances, or official development assistance (ODA). This model has been attacked by Easterly (1999) as a "ghost" haunting the international financial institutions and the economists worldwide (Easterly 2002), because neither in theory nor in terms of econometrics, the basic relationships hold true. Investment is not added up from local and foreign savings $(I=S+M-X)$, insinuating that exports are detrimental for investment and growth, but on the contrary, ever since John Maynard Keynes, it is well established that savings and imports are leakages to demand, and investment is a rather autonomous variable. The formula which is, of course, always true ex post in every variant, has to be written the other way round: To be interpreted ex ante as a residual, or better: an

I Gender aspects are not being treated here so that the male version is used for both sexes, if not otherwise explicited. 
explanandum, namely resulting accumulation, macro-economic saving depends on income generation through investment and exports: $S=I+X-M$. Thus I and X become the crucial variables for growth, not $S$ and $M$. And leaving, for the time being, the export surplus on the current account of the balance of payments to the macro-economics of Chinese development (Priewe 2005, Herr 2002), the micro-economics and the institutional setting of investment, not saving, will be in the centre of attention in the following.

The next step in monetary theory introduces financial assets and liabilities connecting surplus and deficit units, partly intermediated by banks and other financial intermediaries (figure 2). Still, the impression is created that enterprises, as deficit units, can only invest what surplus households and other wealth owners save so that the "theory of finance" (McKinnon 1973, Shaw 1973) is compatible with both neoclassical and Keynesian schools of thought. The capital markets and financial intermediaries become decisive for financing investment, because enterprises are thus modelled as wholly dependent on equity and liability finance, whereas the entrepreneurial functions are delegated to managers, who are not necessarily entitled to profit-sharing, let alone to take all or the most part of the profit as the entrepreneur does in the following model.

Figure 2: Money in a Theory of Finance

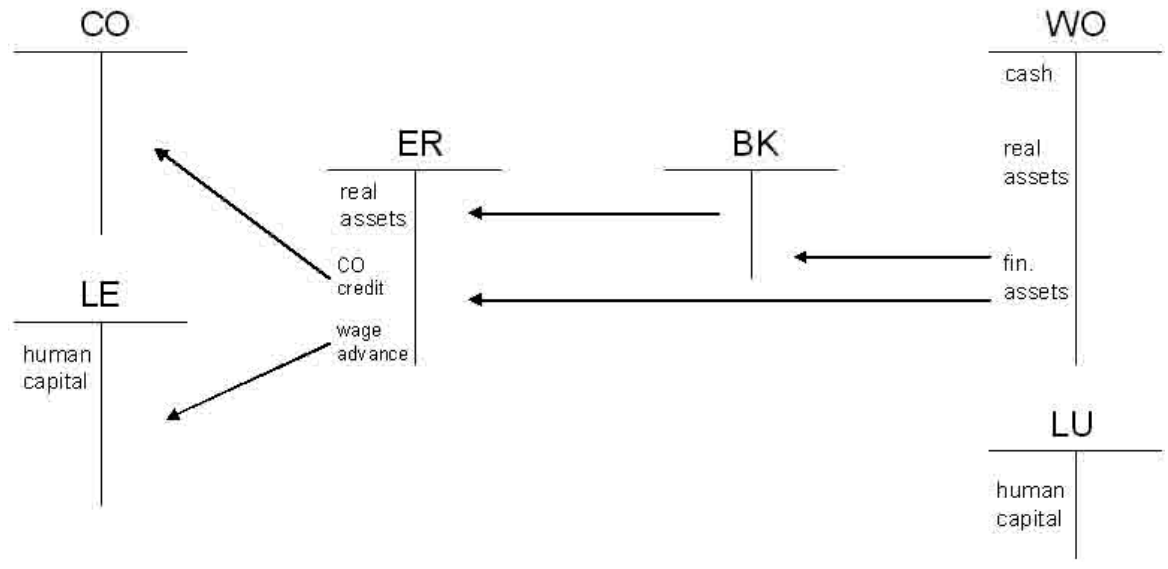

To explain economic development in a monetary economy, Schumpeter makes a fundamental discovery in I9II/I2 which is still not yet fully recognised, but fits in very well with the monetary Keynesian approach: He focuses on the relationship between two main economic agents of any national monetary economy: the entrepreneur and the banker. In Schumpeter's Theory of Economic Development, the entrepreneur does not depend on his own past savings nor on anybody else's foregoing of consumption, but on the credit which the banker is willing and able to hand out to him as a borrower for his investment. In his theory, the lending limit obviously is dependent on the trustworthiness of the entrepreneur as a person and of his project as an innovation to be pursued with profit. As long as the entrepreneur can convince the banker of his future-compliant innovative ideas, the banker will 
finance his investments. The main idea of this concept is that none of the economic agents saved before or concomitant to investment. No "consumption renunciation first« is of any need. Instead, the credit is created ex nibilo (in the original German: "aus Nichts«; "from nothing «, namely without savings): The banker puts his trust into the entrepreneurial ability and the willingness of the borrower to repay the loan. If we take a look at the balance sheets of both the banker and the entrepreneur (see figure 3), we will find a mutual credit relation, namely a claim of the banker against the entrepreneur on the asset side of the bank's balance sheet and a sight deposit of the entrepreneur on its liabilities side.

Figure 3: Credit Creation ex nibilo: Schumpeter's Entrepreneur and his Banker

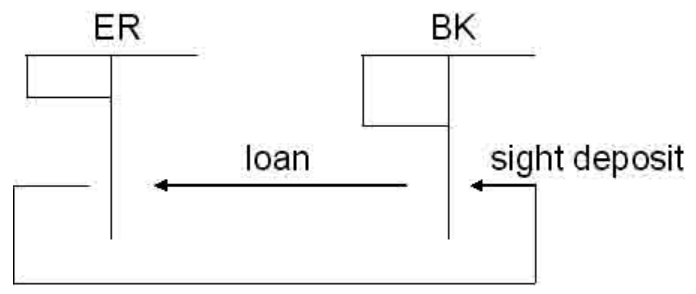

In the next step the entrepreneur needs real assets for his entrepreneurial activities. He will have to buy those real assets from the wealth owner (WO). Their deal will be closed and the entrepreneur will receive the needed real assets from the wealth owner via the asset markets, and he will pay with a cheque on his sight deposit; the bank carries out a transfer from the account of the entrepreneur to the checking account of the WO, provided that the banker is considered trustworthy. In WO's portfolio real assets are substituted by financial assets.

The same happens on the labour market, since the entrepreneur needs to combine real assets with human capital (LE) to carry out his entrepreneurial activities. ER can pay the price for the asset, the interest on the loan, and competitive wages, because he has an innovative project, for which, by the way, possession and control are important, not necessarily definite private property - which lends itself easily for speculation instead of productive projects.

In balance sheet terms, ER changes financial for real assets, and he hires LE giving the worker or employee a wage advance, confident that, in the future, he can sell the innovative product to the consumer $\mathrm{CO}$ (directly or through some intermediary, with or without consumer credit). So far the investment activity of the entrepreneur has been based solely upon financial liabilities and assets. Cash has not come into play yet. But in terms of asset preferences and management, the wealth owner might want to transfer part of his financial assets into cash instead of leaving it on his sight or savings account at the bank (see figure 4, p. 82). The same holds for the worker who might need cash to pay his purchases instead of writing out cheques. Since the central bank is the only institution in a national economy which is allowed to issue money (cash), the lending ceiling for the banker who finances entrepreneurial activities thus depends on the amount of discount credit supplied to him by the central bank. 
Figure 4: Interplay of Commercial and Central Banking: Constitution of a Monetary Economy

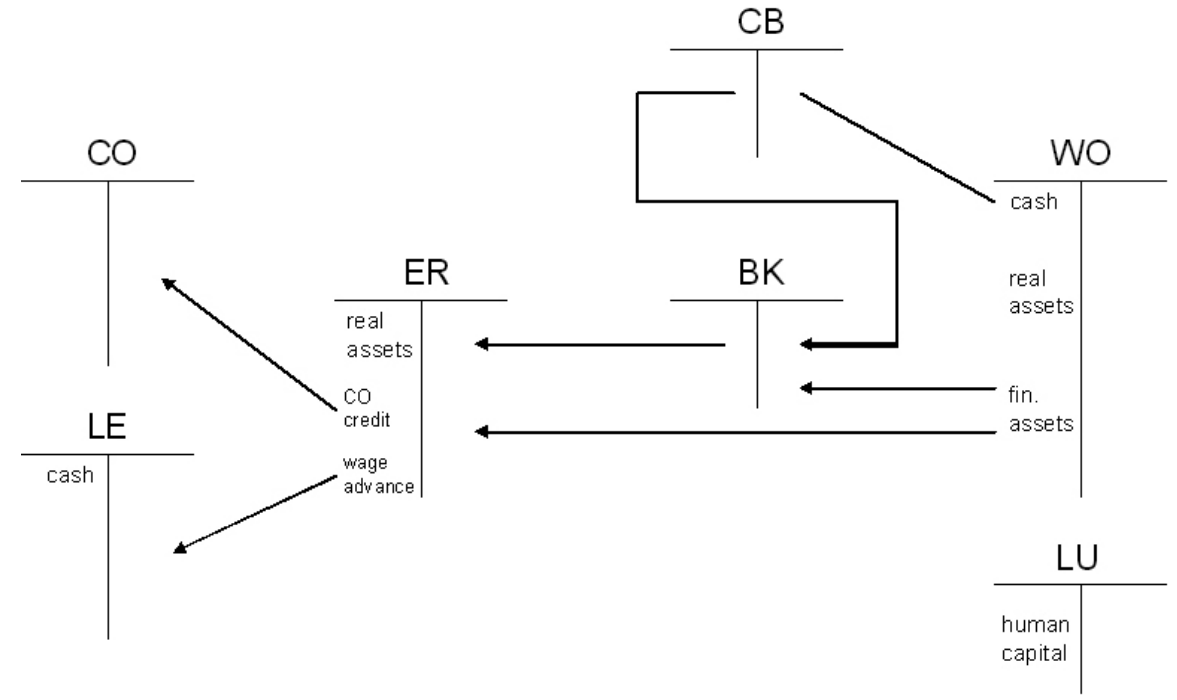

Ever since Walter Bagehot's famous "Lombard Street" of I873 (Bagehot I873/1999, Porcelluzzi 2005), the central bank is modelled as a »lender of last resort " meaning that, in a functioning monetary economy, a run on banks is avoided by the central bank's "lending freely, at a penalty rate, against good collateral $\aleph^{2}$ so that solid, profitable banks are rescued from liquidity crises, albeit no over-indebted ones from insolvency. Again, trust comes into play, because the central banker has to trust the commercial banker not only when he asks for refinancing in such a crisis, but also in their day-to-day dealings. The open discount window enables banks to hold only modest liquid reserves; otherwise no efficient monetary economy would be viable. Thus, the crucial budget constraint on employment and investment is not the vector of real resources but the dominant financial sphere, guided by credit in its larger meaning, namely including trust and confidence beyond bookkeeping numbers.

This is the way money comes into existence in a monetary economy. The main point here to understand is that in monetary economies, money is not only a means of exchange on spot markets, but also, and primarily, a means of deferred payment between creditors and debtors. Furthermore, in our context it is highly important to stress the universality of money as the means for the final redemption from debt and for the acquisition of land, labour and all the other tangible and non-tangible assets necessary for a successful enterprise.

2 The formula in the original text is somewhat more complicated: »[T]here are two rules: - First. That these loans should only be made at a very high rate of interest. [...] Secondly. That at this rate these advances should be made on all good banking securities, and as largely as the public ask for them" (Bagehot 1999: 197). 
To fully comprehend the main argument of this monetary theory of development and underdevelopment, it is highly important to make clear its social division of labour and how the various economic agents are modelled. In this Keynesian monetary theory of development and underdevelopment the Schumpeterian entrepreneur (in the original German: »Unternehmer ) does not own real assets at all, but he is the only economic agent who has got innovative ideas for new combinations of the factors of production. Often misinterpreted, he does not risk his own real or financial assets, because he has none, but he has ideas and entrepreneurial talents, and above all, he has the right to claim the residual, i.e. to make profit. The risk lies with the wealth owner and the banker. Only in the next round, when ER reinvests the profit, he has something to lose beyond his reputation.

The wealth owner is of crucial importance in our monetary economy. He is the owner of the real assets and from the second round on also of the financial assets. He may be what Schumpeter calls a "Wirt", that is an individual who uses his own resources in a traditional way, without major innovations in the neoclassical equilibrium - and without any inherent need for credit! For him, money is first and foremost cash for purchases in spot markets so that the wirt can easily live with inflation, and Friedman's helicopter metaphor might quite aptly model him and his fellow wirte. In an uncertain world, real assets can be hedged against inflation and risk so that it may be totally reasonable to leave a substantial part of them idle. In the model, the wealth owner does not have the ability to figure out new combinations of the factors of production nor is he eager enough to push through innovative ideas. In principle, Schumpeter's wirt is not a victim, because he receives the market price for his assets. However, competition by the unternehmer's new products and his demand for factors of production can and will reduce the market opportunities of many of the traditional producers so that Schumpeter's famous "creative destruction « always comes into the picture - in spite of the assumption of fair asset prices and competitive markets. The more so, when previously »idle« natural capital, not well husbanded or defended by any wirt, is drawn into commercial use and abuse.

Therefore, in order to create economic growth and development beyond what Karl Marx called "simple reproduction", there is need for a secondary distribution of real assets and human capital in favour of the innovative and assertive entrepreneur who is capable of investing in a new and profitable production line. Not being the risk-taking financier, the Schumpeterian entrepreneur risks only his reputation when he fails to service his loan to the banker or the mortgage or dividend to the traditional wealth owner. It is the latter, not the consumer, who becomes the true sovereign of the monetary economy, because he remains with the right and the possibility not to give up his hold on the real assets. Thus his Keynesian liquidity preference is enhancing or blocking the road to employment and growth, depending on his trust in other members of society.

Since the lending bank would not be able to give any loan to any entrepreneur, if the central bank were not in a position to issue money, the national central bank is an absolutely essential institution in monetary economies. This point needs to be emphasised, too: it is very important to understand that both its discount credit to the banks and its money issue are also created ex nibilo, and that they are solely based on the trustful relationship 
with the bankers and with the public, which must be willing to hold cash from that central bank, and not other ones, in its portfolio. It is hard to find any "fundamentals" for these fragile credit chains and money issues in the real economy. This tends to become rather obvious in the case of crises, i. e. when the whole financial building crashes and the motor runs in the rear gear. In this sense, this monetary growth theory is also a theory of underdevelopment, since the concept of investment credit being created ex nibilo (from nothing) allows and indeed suggests the possibility of a credit crunch throwing the economy in nibil (into nothing).

In order to understand the fundamental character of this rather theoretical reasoning about monetary affairs, not only the big leaps from and to nothing are to be considered, but also the marginal steps: Schumpeter's unternehmer normally becomes a wirt when his pioneer profit erodes with competition, and his charismatic entrepreneurial spirit gives way to complacency, routine, and succession. The banker can become a Wirt, too, in the sense that he sticks to financing going concerns, but no innovative investment.

This leads us to two conclusions: (I) In a monetary economy, there is a need for securing normal (»equilibrium«) economic life institutionally for the wirte, including their need for financial services by the banker, and that their life is precarious, too, because it could be stifled by a credit crunch, even though it would not be totally suffocated, since wirte use their own resources primarily, and do not rely on credit for their survival; (2) in order to grow beyond simple reproduction, i. e. an Ioo percent replication of the previous year's gross domestic product, a secondary distribution of capital from the wirte to the unternehmer is essential, and it is here where the social division of labour between entrepreneur, intermediary and status-quo wealth owner on a total as well as on an incremental level and scale comes into play.

A final ingredient of the social formation under debate is the religious touch pervading the whole of society. Confidence stems from the Latin word fides - belief or faith, which draws our attention to the belief system, religion or ethical superstructure, weltanschaunng or cosmological order overarching the trust relations between the individual agents, and legitimising private property, profit-seeking, subtle and stringent control measures as well as all kinds of sanctions when the rules are broken. For the capitalist monetary economy, another classical German text from the pre-World War I period comes to mind: Max Weber's "Protestant Ethics and the Spirit of Capitalism" of 1905 ("Die protestantische Ethik und der Geist des Kapitalismus (), where the religious and ethical foundations of modern capitalism are sought in Calvinism and its puritan offsprings. The restraint on consumption (cis-mundane asceticism - „diesseitige Askese « in Weber's term), the dedication to work as a divine »vocation " by the bourgeois (entrepreneur, top manager, and wealth owner in our terminology), and his accumulative and profit-seeking behaviour are identified as outcomes from specific religious roots and attitudes so that a certain normative varnish is spread over the whole institutional setup protecting it against revolt, revolution, and all kinds of violence.

The question now to be answered is, whether and how Schumpeter's and Weber's pre-World War I, rather Austrian and German world, with traditional - in this case aristocratic - wealth owners, fin-de-siècle entrepreneurs, fundamental technical innovations such 
as automobiles and electrical equipment, functioning banks as well as workable asset and labour markets, and a secularised and generalised protestant ethic even in predominantly catholic regions of Europe, can be compared to contemporary China with its completely different cultural tradition, economic order, and politico-institutional regime.

\section{The Chinese Way}

In the Chinese case, any highly important trustful relationship between the economic agents of the national economy is basically a matter of informal social relationships (关系 guānxi). According to Luo Yadong from the University of Miami, the term guānxi

"refers to the concept of drawing on connections (拉关系 lā guānxi) in order to secure favors (人情 rénqíng) in personal relations. It forms an intricate, pervasive relational network which the Chinese cultivate energetically, subtly, and imaginatively. It contains implicit mutual obligations, assurances, and understanding, and governs Chinese attitudes toward long-term social and business relationships. Broadly, guãnxi means interpersonal linkages with the implication of continued exchange of favors."(Luo 2000: 2)

This concept differs from western networking behaviour especially in terms of its pervasive application among the people throughout Chinese society, consciously or subconsciously, based on its cultural Confucian origin. Indeed, guānxi is a particularly important matter of informal relational contracts between people that somehow feel closely related to each other. In this sense guãnxi is a reciprocal social concept that mainly focuses on mutual emotions (感情 gǎnqíng) between two or more individuals who, while at the same time cultivating their friendship, yet seeking personal benefit. In order to understand this concept more precisely four main terms that refer to guänxi in a larger sense have to be pointed out: social relationships (关系 guānxi), emotions (感情 gǎnqíng), favours (人情 rénqíng), and face (面子 miànzi).

The first expression (关系 guānxi) has got a variety of meanings: concern, affect, matter, relation, relationship, and backdoor connections. For instance, one may translate the phrase méiyǒu guānxi (没有关系) into: it doesn't matter, it isn't of (my) concern, it doesn't affect (me). However, the phrase là guānxi (拉关系) has the meaning of to draw on connections, which means that someone uses one's own connections to secure favours for himself or somebody else. Combining both meanings, it becomes clear that there is both an emotional and a social concept lying behind this term. Guänxi indeed affects emotionally trustful interpersonal relations: no affection, no favours.

The second term (感情 gǎnqíng) refers to the affected feeling involved in guānxi. The more gănqing is involved the closer is the reciprocal personal relationship among individuals. The closer the guanxi, the more reliable it is for mutual material or political favours. One establishes gănqing through gift giving, eating together, coming and going, and social interaction (来往 láiwang). Important to notice: Gănqing does exist in both hierarchical and 
non-hierarchical settings. While it becomes respect (尊情 zūnqíng) from a subordinate point of view, it becomes taking care (爱护 àihù) and trust (信 xìn) from a superior point of view. Among equals it either becomes friendship (友 yǒu) or even love (爱 ài) (Kipnis 1997: 157).

The third term (人情 rénqíng) is often translated into either humaneness, human feeling, relationship, gift, present, or favour. Like gănqing, this term refers to emotions as well. However, in the context of a social relationship, rénqing especially points out that any individual who has got human feelings (有人情 yǒu rénqíng) has got involvement and trustful connections, too. Rénqing actually enables any individual to distribute or secure favours on a reciprocal basis. The last expression (面子 miànzi) is usually translated into face (literally and figuratively), reputation, prestige, and again feeling or sensibility. Someone who has got face (有面子 yǒu miànzi) has the ability to secure favours, too.

Since we have learned that every growing economy needs some sort of institutionalised intermediation between those who own the real assets in the status-quo ante, and the entrepreneurs who figure out new combinations of the factors of production, one needs to understand how the intermediation works in the special case of the People's Republic of China with its Leninist party and state, where collective (not private) ownership of the means of production has been a cornerstone of the socialist economic order. For the last three decades, public ownership has remained dominant, but thousands or even millions of small, but also medium-sized and big private enterprises have sprung up. However, while in the mid-I990s banking has been transformed into something similar to capitalist commercial finance, asset markets have not yet been developed to a major degree, nor are labour markets what they are supposed to be in the Schumpeter model. Therefore, regarding the initial period of reform when commercial banking was underdeveloped and organised asset markets were absent, the main question remains unanswered: how did the Chinese entrepreneur get the real assets from the Chinese wealth owner, and how did the underemployed human capital get employed? In the face of still deficient capital and labour markets and commercial banks, another distributor of resources has to be looked for.

The Taiwanese psychologist Huang Guangguo (I990) divides Chinese society into distributors of resources (资源支配者 ziyuán zhipèizhě) on the one hand side and seekers of resources (请托者 qǐngtuōzhě) on the other. First, before asking for favours, the seeker of resources needs to gain face (作面子 zuò miànzi) by social interaction (来往 láiwang). Once the seeker of resources has got face (有面子 youu miànzi), he is able to draw on connections (拉关系 lā guānxi). Following Confucian rénqing principles (人情法则 rénqíng fãzé) the distributor of resources will then estimate his own benefit, considering the closeness of the relationship between himself and the seeker, thus calculating how much emotion (感情 gǎnqíng) actually is involved. Afterwards, the distributor decides whether or not to grant the favour (人情 rénqíng).

Note that it is really important to understand that the distributor might withdraw an earlier favour. If the distributor fails to meet the requests of the seeker, the latter loses face (失面子 shī miànzi). However, if the distributor decides to allocate favours to the seeker, the latter, in fact, receives rénqing (人情) from the first. This is the way how both economic agents reinforce their relationship (加强面子 jiāqiáng miànzi: reinforce face). Obviously, 
the relationship between the seeker and the distributor in this Confucian »rénqíng-miànzimodel " (Huang I988), which describes the micro-economic foundation of the Chinese guānxi economy, comes close to the relationship between the Schumpeterian entrepreneur and his banker, and their mutual credit. This is especially true because normally, in China a given favour is, analogous to the bank credit, interest-bearing to the distributor's advantage (Yang 1994: 143 f.).

The entrepreneur can be taken for granted, once private appropriation of profits has been allowed in China, and the potential for innovation, too, since the people's communes and enterprises of the state socialist era certainly left much to be desired in terms of the development of productive forces and modern technology. But where does one find Schumpeter's banker or, in terms of the already explained Chinese social relations, the distributor of resources? How are traditional wealth owners involved in this game of modern economic development? And what kind of "cosmic « order is prevalent in the superstructure of society?

Before looking for the equivalent to Schumpeter's banker, the existing Chinese banks deserve some attention. Especially during the initial reform period, the banking system used to be set up like a traditional communist monobank system, subject to orders from planning officials and other authorities. Financial intermediation barely existed, and the investment of the fledgling township or village enterprises, torn between informal privatisation and formal state ownership, was financed on command from above, and not subjected to serious evaluation by any bank. Even though the monobank (People's Bank of China - PBoC) had a few branches, which had to fulfil special tasks, they solely had to implement the central credit plan that was made up by the State Council and the Ministry of Finance.

Under these circumstances, neither the traditional wealth owner nor the banker could provide the entrepreneur with the necessary means of production, manpower, access to markets, and all the kinds of permits and complementary infrastructure and logistic requirements one needs for opening and running a modern business anywhere, let alone in a socialist country. Various kinds of power beyond the market are always needed - and the clue to the Chinese power structure is the Communist Party of China (CCP), which has run the country since the civil war and the foundation of the People's Republic of China in 1949.

The CCP is a party in the Leninist tradition, which means that it considers itself and its members as a "vanguard" in the sense of a hierarchical organisation structured by the principle of »democratic centralism«, leading the country into a bright future and knowing better than ordinary people what is right and what is wrong, in all dimensions of life. The resulting "vanguard mode of production « (Lebowitz 2000) is characterised by a strong corporate identity of the clergy-like party which is, in fact, the only institution which guarantees the degree of cohesion or coherence which is necessary in every society. Cohesion, in turn, requires universal power and means of intervention. Contrary to a capitalist market economy where "le monde va de lui-même" (»the world runs by itself"), as the famous dictum says, the vanguard leadership of communist parties in socialist countries requires deliberate decision-making and coordination on every level and between the levels of power, when the comprehensive mission is to be accomplished or at least not completely failed. Since no »invisible hand " (Adam Smith) can be conjured in an economy with still largely 
administered prices and asset markets which until today do not yet compare with those in mature capitalist countries, personal relations based on individual responsibility and visibility have to secure coherence in day-to-day affairs as well as in the "cosmic " order stemming the forces of "chaos « in the superstructure of society. Thus mutual confidence or trust between persons - guänxi - is not something which exists in various forms and in an immense variety of social relations everywhere in the world and at every time in history, and which, in contemporary China, is or might be somewhat more important than in a market economy, but there it has a markedly different, pivotal, essential place in the working of the economic system, and not only an accidental one, so that the terms "guänxi economy « for the recently developed mode of production in Mainland China and "guannxi economics« for the theoretical approach to come to analytical grips with those phenomena in the real world are suggested here.

Analogous to the credit-deposit relation created ex nibilo between the entrepreneur and the banker in Schumpeter's world, the CCP secretary enables the entrepreneur by command ex nibilo to get hold of the resources, manpower and permits he needs for an innovative investment, when both of them trust each other and when they are confident that the enterprise will yield a profit, which is appropriated by ER, but somehow "shared " by the party secretary, be it in monetary form or in the form of an enhancement of his power base with regard to the control over resources or of his reputation so that he can climb the ladder within the party and/or the state bureaucracies.

In 2005, the CCP still had about half a million leading party cadres (Heilmann 2004: 84) among approximately 70 million Chinese Communist Party members ${ }^{3}$, when party secretaries were, and still are, heading the party cells (党支部 dǎngzhïbù) on each level and within each compartment of the state apparatus, the public utilities and generally also within the production units and housing complexes. The local party secretary, who heads the assembly of secretaries from the different local administrative and productive units, is so powerful, especially in the countryside, that he is often referred to or even addressed by his local constituents as local emperor (土皇帝 tǔhuángdì), not because of his formally high position within the structure of the party hierarchy, but because of the fact that he actually rules a large number of people in a certain area - a village, a county, or a district (Wibowo 2000: 4, Heilmann 2002: 96). Like everywhere else in the world, on every level, the state in China is compartmentalised into ministries and similar agencies with specific functions which are headed by a government as the executive power. Without functioning markets, media, and legislatures, and without a central bank, neither the orientation of day-to-day decisions nor the securing of coherence in long-run policies can be expected from this conglomerate of partial bureaucracies nor from its chief of government. It is the Leninist party which holds society together in the name of the people and its future destiny - in Lebowitz' lucid term a "vanguard mode of production" (2000).

3 People's Daily Online, visited on Jan 2Ist, 2008: „Members of Communist Party of China grow to 70.8 million«, URL: http://english.peopledaily.com.cn/200606/19/eng200606I9_275246.html. 
During the initial period of reform command ex nihilo works as follows (figure 5, p. 90): In a legal framework consisting of a rather conventional state structure, a vanguard party, a monobank system ruled by the central credit plan, and finally a local dànwèi (work and administrative unit) system of operating village enterprises and similar de facto wealth owners of the formally "nationalised « real assets, the local communist party secretary is able to order the local dànwèi to hand out the requested real assets to the local Schumpeterian entrepreneur. The same happens on the local labour market. Underemployed labour from the local work units will be instructed by the party secretary in power to start working for the local entrepreneur. Finally, the local representatives of the state bureaucracies are ordered to issue the necessary licences and permits and to provide the infrastructure and logistics. This command structure only works because the leading cadres to whom the orders are directed are generally also guānxi-related party members, i. e. comrades, whose promotion in business, administration and politics depends upon obedience to their superiors and good relations with their peers, and because there is, or at least should be, always some kind of "consideration " (quid pro quo) for the withdrawal of resources. Throughout the People's Republic of China, the party secretary is the commander of the guanxi economy so that every citizen of Leninist-ruled China relies and depends on the resource allocation power of the Communist Party and its secretaries. However, it is important to understand that the resource distribution by the local party secretary's "command " is based not only upon authoritarian power, but also upon a trustful guānxi relationship between the local dānwèi and the administrative state officials concerned on one side, and the entrepreneur on the other who is now in a debtor's position against the party secretary, while the latter is in a debtor's position against the local dänwèi system which, in turn, has to respond to the claims of its members and creditors. In this sense, the party secretary substitutes the financial intermediation of the capitalist system in a rather efficient way providing coherence to an otherwise chaotic economy, while the Chinese banking system of the monetary economy is still on its path to gradual capitalist development.

Let us now look at the wealth owners (WO). In pre-reform communist Chinese society, the central state as the representative of the "people" was the formal owner, but the decisions about resource use were decentralised, the state units as parts of the Chinese politico-administrative dānwèi system being in fact what one can call »owners" of the natural resources and the other real assets in the People's Republic of China. On the local level, the state was formerly divided into communes and brigades running commune and brigade enterprises, whose production teams (生产队 shēngchǎnduì) were in charge of using farm land, factories, manpower, and natural resources. During the initial period of the reforms, the smaller commune and brigade units where renamed township and village enterprises. In any case, different from Schumpeter's Austrian background, wealth owners were not individual persons but collectivities in different legal forms. When trust as an exclusively human trait is supposed to be as important as assumed and explained so far, the modelling of the individuals behind those collectives becomes indispensable. Since the claims of these persons is highly important when it comes to a comprehensive understanding of "development « in all its dimensions, these owners and claimants are abbreviated as »other cred- 
Figure 5: Guanxi Economics I- Command ex nibilo

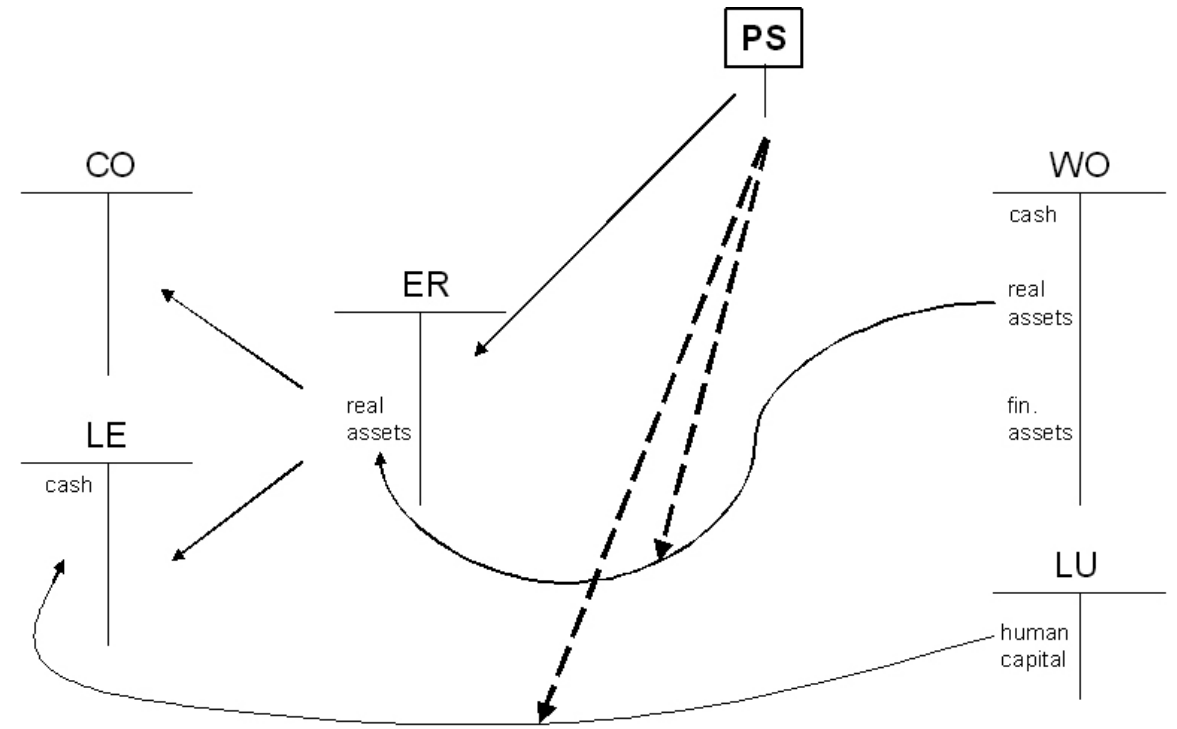

itors" (OC) in the following for simplicity's sake. A closer look reveals the equivalents of both categories on the right hand side of the balance sheet: liabilities and equity so that you might also interpret the term OC as "owners and creditors". It should thus have become clear that the collective wealth owners (WO) as well as the ultimate individuals involved as owners and other creditors (OC), are also indirect "creditors" of the new entrepreneurs, and that those WO-collectivities are themselves, like banks and/or their substitute the party secretary, institutional intermediaries, subject to their managers, members/owners and creditors (see figure 6).

As already hinted at, our party secretary should not be misunderstood as being only a single individual person. We should rather consider the "assembly» of party secretaries on each level as the decisive nucleus of the command structure, where one party secretary might have been in charge of the rather traditional township and village enterprise controlling the asset in question, another one or more have been located within the "regulating state authorities involved, and another one in the township and village economic commission. These informal and rather flexible assemblies have often been called small leading groups (领导小组 lǐngdǎo xiǎozǔ) that are set up spontaneously and $a d$ hoc by party secretaries on each level of the party state (Shirk 1992: 64f., Heilmann 2004: 80 ff.). However, as Jean C. Oi has observed, the lower down the hierarchy the more a single party secretary might get involved in direct entrepreneurial activities, running even the innovative company, and chairing the board of directors of the local economic committee, or being in charge of other local political duties: 
Figure 6: Guanxi Economics II - Command plus Comprehensive Avantgarde Party Responsibility

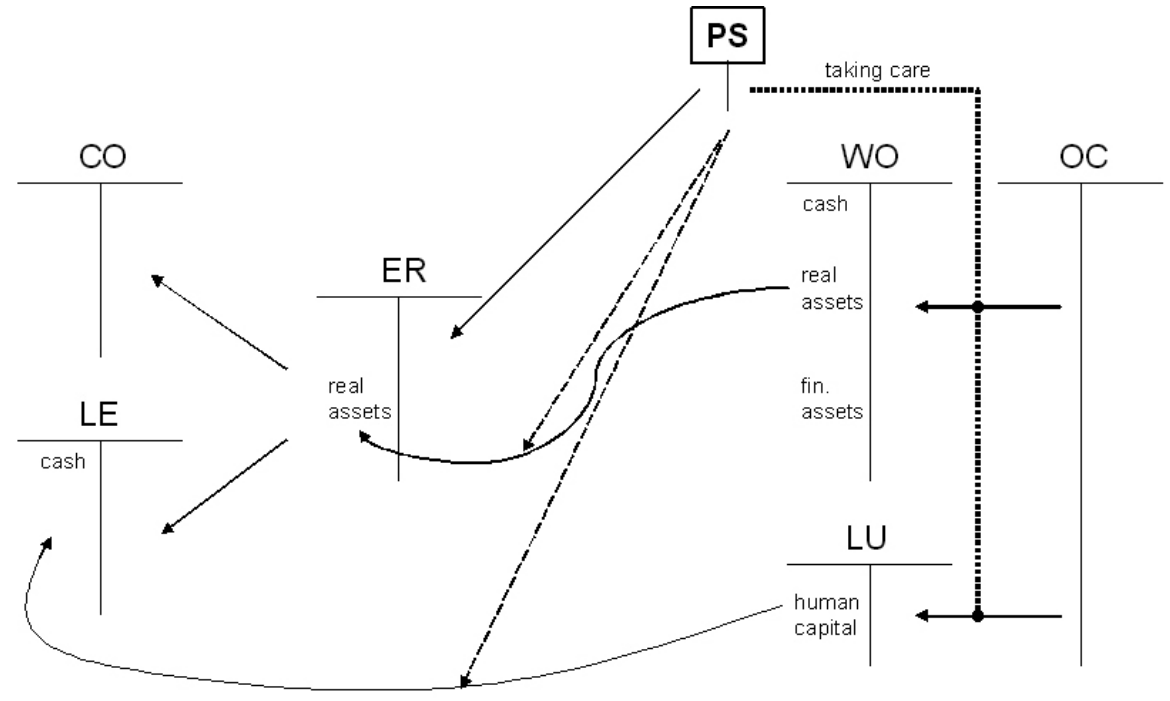

"The lower down the hierarchy, the more intimately cadres are involved. Most visible is the village party secretary, who can be found personally intervening in the economic decision making of the village's enterprises, often chairing the board of directors of the village enterprise management committee."(Oi I999: IO2)

Since in a traditional socialist economy, the resources of society are formally nationalised, but no national institution is really in charge, the local assembly of party secretaries turns out to be the real and actual informal owner of the real assets (Kornai 1995: 79), and the same assembly of party secretaries has also access to all the other factors of production and to the regulating agencies, because party secretaries are at the head of the danwei system, too. Being in a position not only to redistribute and reallocate resources, they actually are also able to initiate new and innovative production lines themselves within the dànwèi enterprises, and there are instances of successful modernization of those contemporary Chinese wirte within the public sphere (Lau 2006).

However, the description of these endeavours shows that the processes are slow and very laborious, and that rather heroic personalities and favourable circumstances are necessary for achieving significant economic growth, whereas the transition of resources from a public, collective (= de facto no-owner) wirt to a private unternehmer, with the party secretary as intermediary substituting Schumpeter's bankier, seems to be the dynamic prime solution to the Chinese growth puzzle, because it provides a powerful incentive for the party secretary and his fellow party members to transfer public to private ownership efficiently, and to benefit personally from that transfer, either in money or reputation or socio-political 
terms. This view makes it highly probable that the big boom will be over, once there is "nothing left to steal« in the sense of no underemployed public resources left to be privatised. After that stage, the ER can only get relatively idle resources from other private owners, who always have the sovereign option to hold them back and hoard, and to continue their going concern or to speculate on further asset price increases. However, the history of authoritarian political regimes with capitalist economies shows that private property is not always an insurmountable hindrance for heavy state dirigisme.

In the transformation phase, the local assembly of Communist Party secretaries has not only got access to every specialised agency of the state, and it is not only in charge of the reallocation of property rights on real assets, but it is also responsible for taking care (爱护 àihù) of the needs of each member of society, namely the OCs, often the victims of change (see figure 6). During the reform process, the Communist Party secretary has been and increasingly becomes an economic agent, but, in the first place, he has still remained a political institution. Consequently, our PS is not only accountable to the shareholders of the innovative economic activities of the Schumpeterian entrepreneur, but he is also in charge of the whole infrastructure of the local danweì system, the employment of its members in the local enterprises which are still under public control, and the social security of the non-active members of society.

To give a concrete example for the early reform period: when the local district party secretary decides that a traditionally managed pasture is transferred to an ER who promises to establish an apple plantation and an apple juice factory at that site, one party secretary is supposed to take care of the children playing there so that they get a place in the local kindergarten, another one is to provide a place for the shepherd in the local retirement centre, a third one is held responsible for the children and the elder relatives of the woman who is to work full-time in that factory, and a fourth one has to be compensated for the wool and meat of the sheep which had been used by "his« economic unit. The permit-issuing institutions, from the local fire department to the environmental and labour, construction and city planning agencies, are also, up to a certain degree, under his control. Since there is only one first party secretary responsible for every village, township or county, the members, employees, pensioners and/or just citizens, users and beneficiaries of the state agencies and enterprise are at his mercy as »other creditors (OC)« (see figure 6). Like always in credit relations, the dominance is a question not only of who is in which chair, but also of who is more dependent on the compliance of the other. As a rule, the comrade party secretaries are urged to take care (爱护 àihù) of the OCs, since those are typically the »victims« or »losers« of the reform process, since factors of production are taken away from them.

The search for legitimising principles which support the complex ordering of this »creative destruction « leads to the question of how to find Max Weber's quasi-religious normative order in contemporary China. Is there a modern, new Confucian combination of "command ", "comprehensive, holistic responsibility", and "righteous leadership»?

In traditional imperial China the absolute power held by the emperor - the "son of heaven « - was religiously legitimated by a (temporary) "mandate of heaven«. After the civil war the CCP replaced this heavenly mandate by the quasi-religious » mandate of history» of 
Marxist historical materialism, and in recent times the developmentalist economic-growth mandate of global capitalism was shrewdly incorporated. However, the predominant historic notion was not one of eternal bliss but of recurrently rising and falling dynasties, where empires fall once the terminable mandate of heaven (or history) is withdrawn. This concern still haunts the party when it pushes ideological campaigns like the last great one put forward by Jiang Zemin, namely sān ge dàibiǎo 三个代表 (»Three Representations«), when in 1999 he led up to the preparations for the $16^{\text {th }}$ party congress announcing that in the future, besides representing as the first group the "working class, peasants, and soldiers", namely the majority of the masses, the CCP will as a second group also represent the wadvanced productive forces", among them profit-maximising entrepreneurs with privately owned means of production - who, after the year of 2000, where finally allowed to enter the CCP, now being able to "draw on connections" (拉关系 lā guānxi) within the vanguard party structure itself -, and as a third group the "progressive forces of the cultural sector".

In fact, much like in dynastic times, the leadership of the "great" chairmen Mao Zedong and Deng Xiaoping was not only built upon a mandate from »heaven«, but also upon a "mystic", personal charisma in the same vain as Max Weber had put it in his other famous book "Economy and Society (in the original German: "Wirtschaft und Gesellschaft" of I925). It looks as if the Chinese have reclaimed their Confucian communist party »virtue" as a synthesis of both Max Weber's "Protestant Ethic « and his "Charismatic Power « clothed in Chairman Mao chants, and that contemporary global »developmentalism « represented by the famous saying of Deng Xiaoping: »It makes no difference whether a cat is black or white; as long as it catches mice, it is a good cat“ (不管白猫黑猫, 抓住老鼠是好猫 bùguǎn báimāo hēimāo, zhuāzhù lǎoshǔ shì hǎo māo), reckoned as a justification for privatisation and socio-economic stratification by legitimising the enrichissez-vous (enrich yourselves) of the new capitalist class.

This way of conducting politics on the side of the party leadership, and perceiving it on the side of the constituents, seems to rest

"on a deep-seated belief in the sacrosanct nature of political authority and in the categorical differentiation between the ruler and the ruled." (Zhou 2005: I70f.)

And this might, in fact, explain why the authoritarian power of the Chinese Communist Party is rather widely accepted among the Chinese people and also among entrepreneurs. The citizens of the People's Republic of China even seem to respect (尊敬 zūnjìng) the vanguard role of the assembly of party secretaries, perhaps just because the latter do exactly what noble men (君子 jūnzí) in the ideal Confucian society are supposed to do: they take care (爱护 àihù) of other people. After all, power and righteousness are two sides of the same coin in the characteristics of every mode of governance. The political system of the People's Republic of China has thus kept a (tiny) window »open « to change, if not revolt or even revolution in the case of non-righteousness, and also to the rise of those "subjects" to become "rulers" themselves, who adhere to the generally accepted rites (禮 lî) and the ideology of the vanguard party, thus enhancing competition, innovation, and elite rotation among "old « and "new« party secretaries. Unlike for instance Aristotle, the classical Confucian thinker Xunzi 
believed "that men are born equal in all ethically relevant respects" (Rosemont 1971/2000: 4); and that "children [...] cry with the same voice at birth, but as they grow older they follow different customs. Education causes them to differ.«(荀子: 勸學, Watson 1963: 15) Consequently, every man has got the ability to become a "noble man" (an ideal ruler), when he has learned to follow »the way" (道 dào). He argues: "The gentleman is by birth not different from any other man; it is just that he [...] [has become] good at making use of things." (荀子: 勸學, Watson 1963:I6) Indeed and with respect to the CCP, in the course of the reform period, it has become highly attractive for Mainland Chinese to enter the "vanguard" party and to make a career as party secretaries on the various levels. In 1995, the CCP in fact experienced its largest increase of membership since the end of the Cultural Revolution (Wibowo 2000: 4), and the above mentioned competition and elite rotation within the party finally remind us of the structure of the ideal Confucian society, where every man has received the natural ability to become a noble man (君子 jūnzí) himself.

The fact that in contemporary China this "noble« party secretary benefits from his partnership with the entrepreneur, be it through career enhancement on the political ladder or by keeping a share of the entrepreneurial monetary profits for himself, is not contradictory to Confucian thought at all: while making a career as a "noble man", the party secretary is allowed to benefit or make profits (利 lì), as long as he puts weight on righteousness (義 yì) (論語 Lúnyǔ VII I5, XIV I2, XVI Io, Bao/Lao I992: II7, 239, 289). Note: as long as the other creditors (OC) believe that the party secretary will act like a traditional "noble man", i. e. that he will adhere to righteousness (義 yì) in concordance with generally accepted rénqing principles and Confucian traditions, they will also accept his self-interest in benefitting, even in keeping a share of the entrepreneurial profits.

So far, the legitimacy of the "grand design" of the social credit chain between the Communist Party, the traditional wealth owners, the assembly of party secretaries, the Schumpeterian entrepreneurs, the employed and the unemployed labourers, and the other creditors has not yet been broken. However, there always looms the peril that the powerful will lose their "mandate of heaven" and their usurped "will of the people» (volonté générale). Obviously fearing an upcoming legitimacy crisis at the dawn of the $\mathrm{II}^{\text {th }}$ five-years planning horizon (2006-20IO) - since China is facing growing regional income disparities corresponding with rising unrest among the poor in the hinterland (Chen/Wu 2004), and in order to meet the expectations of the "masses « for social balance - State President Hu Jintao in 2004/2005 unsealed the campaign of a "scientific concept of development« (科学发展观 kēxué fāzhăn guān) combined with his vision of a "harmonious socialist society《 (社会主义和谐社会 shèhuìzhǔyì héxié shèhuì) (Holbig 2005). Against this background, the tense discussion about the equal protection of state and private property and the reform of the "re-education through labour" system at the National People's Congress in March 2007 shows clearly the tightrope walk the CCP follows with its comprehensive developmentalist approach.

On the side of the entrepreneurs, these economic agents so far not only seem to respect the authoritarian rule of the Communist Party secretaries, but they are even eager to make use of their mutual guannxi, in order to receive privileged access to real assets and human capital, as Howard Davies et al. (1995) discovered in their survey on business strategies of Hong 
Kong entrepreneurs with Mainland Chinese. No wonder that their cry for democratic reforms along Western lines is not all too loud (Joffe 2003) - this seems to be especially true since, as already mentioned, after 2000 , entrepreneurs have been able to gain even more privileged access to resources since being accepted as party members.

An authoritarian vanguard party system would become dysfunctional, if it was not based upon a certain degree of mutual trust between the various economic agents beyond party members in a comprehensive, all-encompassing way. There must exist not only some sort of quasi-religious varnish, but also, in more practical terms, an universally accepted »currency « for »deferred payments « honouring medium and long-term obligations beyond the purely pecuniary sphere in the Chinese communist society. The official Renminbi or Yuan is mainly used for transaction purposes and, of course, increasingly also in the fledgling monetary economy with its formal financial markets, but obligations and claims bridging past, present, and future have only very cautiously been denominated in Yuan terms.

How then, in the initial period of reform, is confidence among debtors and creditors involved in economic transactions created and expressed? Why should any local dànwèi party secretary or director supply real assets to any Schumpeterian entrepreneur, if he could not expect, with high probability, at least some kind of remuneration for himself and for his OC-constituency in the future? Especially if a certain deal is based upon an informal, relational forward credit contract - why should the former wealth owner put any trust into his counterpart, believing that he, or somebody else, will be willing and able to pay back an informal loan in the future? In short: is there an equivalent to money? The answer to this question is again guānxi, together with the already mentioned rénqing principles, based upon traditional Confucian rites (禮 lǐ), humaneness (仁 rén), trust or reliability (信 xìn), and righteousness (義 yí). Just like the central bank refinances Schumpeter's banker, when instead of sight and saving deposit services (which he can deliver himself), the wealth owner and the worker want to see the universally accepted cash (which he cannot produce himself), the Communist Party »refinances" the individual party secretary (see figure 7, p. 96).

Party members, and party secretaries in particular, in all the administrations and enterprises involved take care of the victims honouring the explicit or implicit, actual or virtual promises like "vouchers" (quasi-bank notes) which they receive for giving up their control over the resource. The party members can thus provide the ER with the necessary inputs, amenities and permits, and look after the necessary infrastructure so that a coherent accumulation process under the joint leadership of the private entrepreneur and the party can take place.

However, in the case of an emergency (equivalent to a "run« on the bank), Bagehot's rule should apply here, too: "Lend freely, at a penalty rate, against good collateral!« As long as the individual party secretary behaves and performs well, the local assembly of party secretaries and the upper echelons of the party are willing to bail him out and "refinance« his debt, albeit with rising remuneration rates. As in the Schumpeterian world, the entrepreneur has to compensate his party secretary, be it in cash, resources or reputation, and along the relevant guānxi lines, the party secretary has to "pay" for his refinancing and to remunerate his fellow party members and his superiors in money or - more importantly - in terms 
Figure 7: The Communist Party as quasi-Central Bank

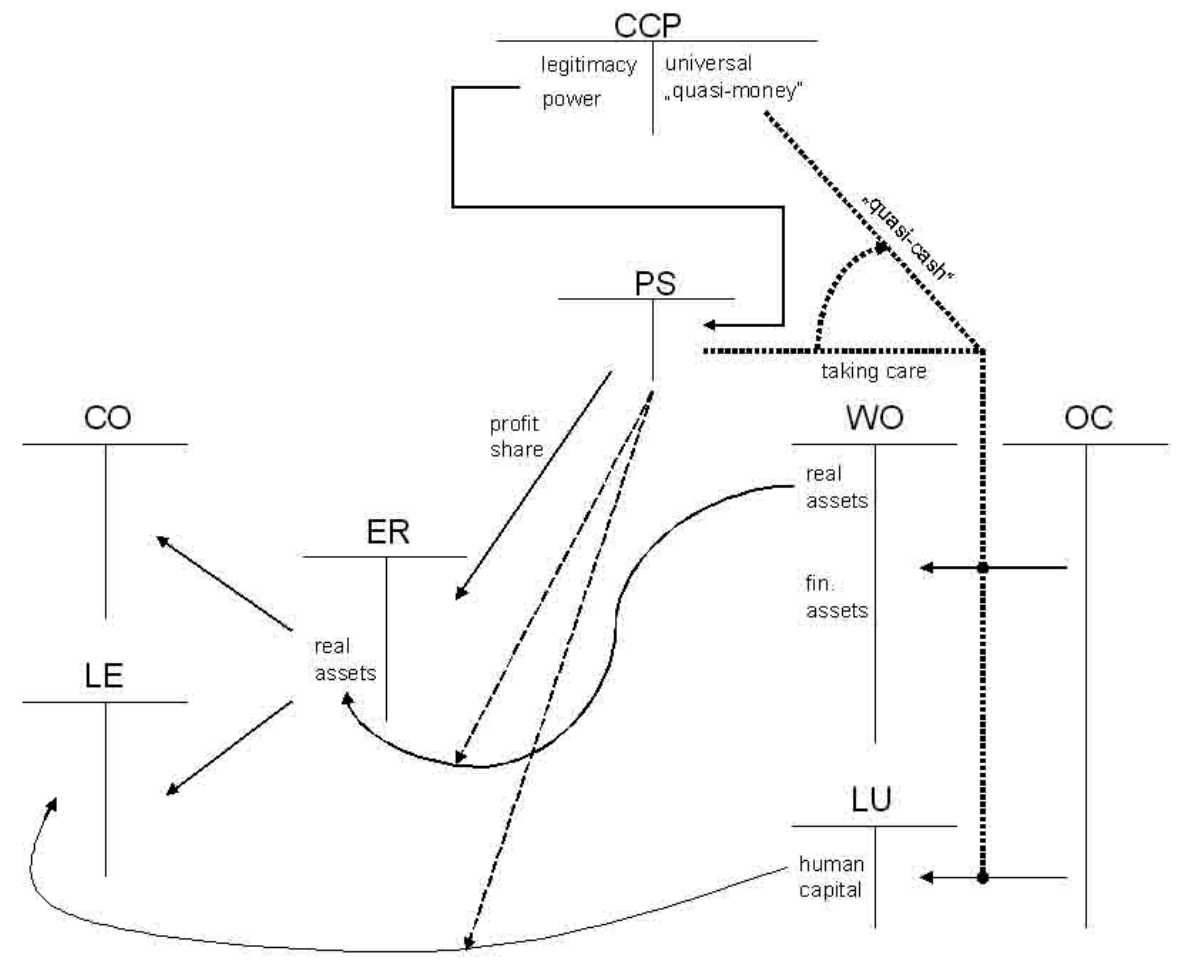

of political support and by using his own distributing powers to "refinance« his comrades with resource access, permits and other "command" measures at his own disposal, when they themselves help an entrepreneur to start a business ex nibilo. It may sound anathema to compare a communist party with a central bank, but do not both of them provide the universal means for the allocation of resources and for the payment of debts in society? Do they not both separate the haves from the have-nots? And above all, do not both of them guarantee coherence of the economy?

Furthermore, similarly to monetary economies, it is hard to find any "fundamentals" for these trust chains in the real Chinese guanxi economy. Therefore, the whole building might crash and the guānxi motor might run in the rear gear as soon as the participating economic agents lose faith in the Confucian principles. In this case, command ex nibilo can indeed also turn into a trust (=credit) crunch throwing the whole guãnxi economy in nibil (into nothing). Anti-corruption campaigns and other moralising endeavours of the ruling party are thus of more than accidental importance, since they resemble banking supervision measures in monetary economies, if not puritan sermons. A look at further developments of the Chinese case in recent years should shed a light on the question whether this distinction between a guänxi economy and a capitalist monetary economy should be looked upon as a categorical or a gradual one. 


\section{Political Development Banking: guānxi Economics Everywhere}

In order to understand the dynamics of the Chinese economy, a closer look at the individual actors is warranted. What has actually happened underneath the formal institutions during the second phase of the guänxi economy, when, in the mid-I99os, the open "command " phase was over? The monobank was transformed into a diversified banking system, including development banks promoting investment of enterprises of all kinds along political priorities, but not necessarily irrespective and unscrutinised with regard to economic viability. Both the party secretary and the former WO, or better its former directors, have step by step become either entrepreneurs or remained politicians or administrators, or have become rentiers in the sense of persons of private means enjoying the rent they had sought in the previous phase, as bond- or shareholders of the newly founded innovative enterprises (with or without foreign investors, who are not treated separately here, because that would open up a different topic, without adding substantial value to our basic argument). The OCs have or have not been indemnified for their sacrifices, and if you include nature here, the grave ecological problems of China pinpoint to the fact that she has never had a voice in any human society, and that monetary, socialist, and guānxi economies unfortunately do not seem to diverge much on that issue. Without advocates such as non-governmental organisations and committed individuals with access to the media and legislatures, i. e. without freedom for the formation of public opinion, there is not even much hope for the better, when the standard of living improves while nature suffers.

The situation of the party secretary deserves special attention as a quite peculiar one, because we are talking about a socialist state where collective ownership remains large, if not dominant. The party secretary might have become an economic agent throughout the reform process, but he still is primarily a political agent who remains responsible for the tasks and orders he receives not only from his superiors and peers, but also from the local members of the vanguard party with its claim to comprehensive, holistic responsibility, on which it is also held responsible, even in the guided media in China. In order to shield himself from political as well as personal responsibility, he has every incentive to leave more and more routine decisions to the new banks, which are increasingly assuming those functions which commercial banks have in capitalist monetary economies. In addition, with the rise of private property the power of the party is waning, since markets »run by themselves«, without the interference of visible party hands and thus without the need for guanxi as an essential trait of the dominant mode of production.

When only major investment decisions are left to the highest echelons of bank governance, the situation begins to resemble the one of ordinary politicians in all countries of the world, who try to direct credit and investment according to political criteria, without necessarily being members of a single "vanguard « party. That is why our abbreviation in figure 8 , p. 98 changes from PS (party secretary of the CCP) to PN (ordinary politician everywhere).

Political (development) banking has been known in all contemporary economies, and on a closer look, every major innovative investment needs not only a commercial banker and functioning asset and labour markets, as implied in Schumpeter's model, but it also needs 
Figure 8: Guanxi Economics III - Politicised Development Everywhere: Banking between Developmentalism and Amigo Banking

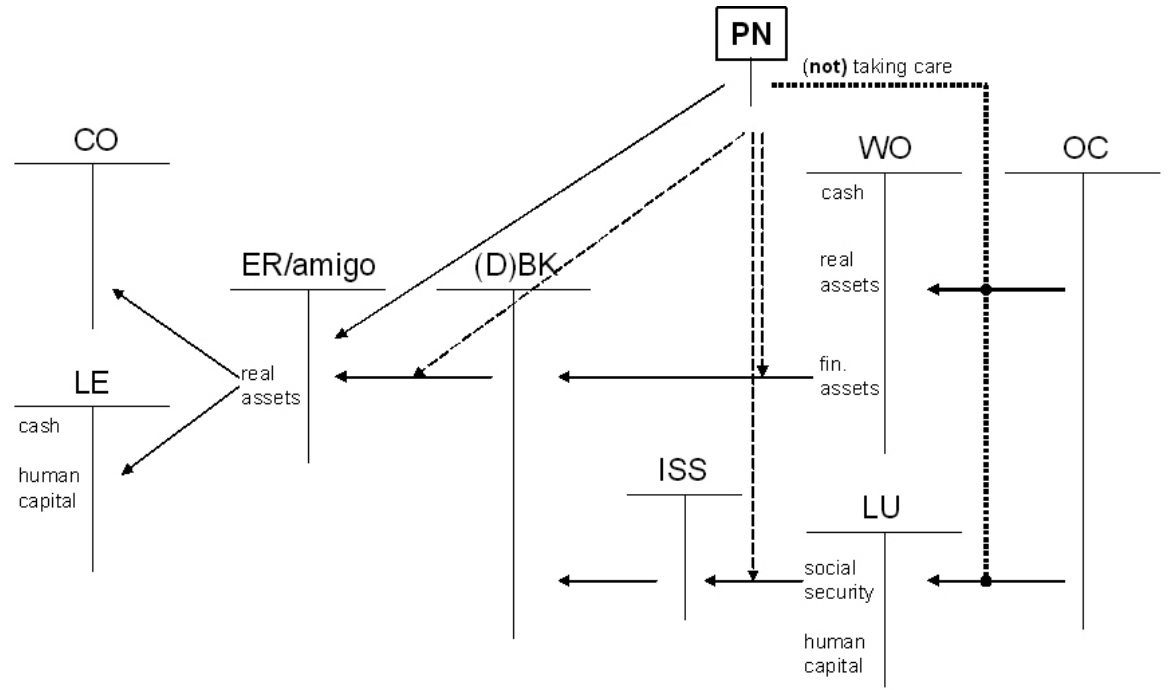

permits, accompanying infrastructure investment, and the solution of output market and raw material access problems beyond market forces - so that trust and mutual confidence among persons from different social institutions turns out to be a rather universal trait of economic life. Guānxi is supposedly the clue to contemporary China's economic growth, but there is evidence and logic in the assertion that it is not totally incompatible with a market economy and capitalist banking, because the "local emperor « would lose much, but not necessarily all of his power in the transition process. It would even be compatible with multiparty democratisation, once coherence is no longer guaranteed by the party but by functioning markets and banks, including the central bank - which does not even necessarily have to be independent. The more or less democratically elected politician might substitute the party secretary, once markets and money make the economy gradually »run by itself «. The litmus test of who is winning the rivalry between the party and the market lies in the access to resources: are they auctioned off in the marketplace, or adjudicated by administrative fiat? Which of the two allocation mechanisms with its concomitant superstructure becomes prevalent? Most of the economies of the world are characterised by structural heterogeneity, meaning that different modes of production coexist in the same social formation, with one of them on the top (Nitsch 1999 und 2002). This is also true for contemporary China, where the struggle for hegemony has only begun. No quick resolution is to be expected. After all, trends of authoritarian party rule along guänxi lines often creep into profoundly capitalist societies, be it on the national, the regional or - quite usual - the municipal level.

Thus, not only Schumpeter and Weber show themselves as rather reliable guides to the mysteries of contemporary Chinese growth, but also guänxi economics turns out to be much more pervasive than being confined to China. However, nowhere else in history and space 
has the typical Chinese guānxi constellation evolved that puts personal trust and confident party backing into such an extremely important, pivotal place within a complex institutional structure that it could and should be called a mode of production sui generis. This set-up was probably never designed by a mastermind, but it seems to be a peculiar trouvaille of history stemming from a stalemate within the CCP between reformers and conservatives, where privatisation in favour of entrepreneurs from the one hand side remained balanced by the predominance of public property and its gradual, if at all, transformation, and by the maintenance of absolute power by the party and its local secretaries on the other. A brief comparison with the Russian (and other East European) experience with transition or transformation shows the singularity of the Chinese way.

\section{Big Bang Economics in Russia and Beyond}

Transformation from the socialist mode of production to other social formations takes different forms and paths. From our point of view, the »big bang « reform path followed in Russia supports our argument.

Gorbatchev loosened price controls within his perestroika policies, allowing enterprises to set their own prices and to run into debt with the monobank and its subsidiaries. This led to an accumulation of debts in the balance sheets of both state enterprises - as statusquo ante wealth owners (WO), in our terms - and banks. In the beginning, state bonds were offered to the banks, crowding out loans to private entrepreneurs (ER), which were officially encouraged, but lacked access to credit and capital (see figure 9). It came as no surprise that over-indebted WOs and BKs did not attract the most serious and honourable businessmen when privatised, whatever the modalities, vouchers, management buy-outs or outright sales, but fell into the hands of what was later called »oligarchs" or »mafias«.

Figure 9: Perestroikal Big Bang Economics - Paralysing Loss of Coherence
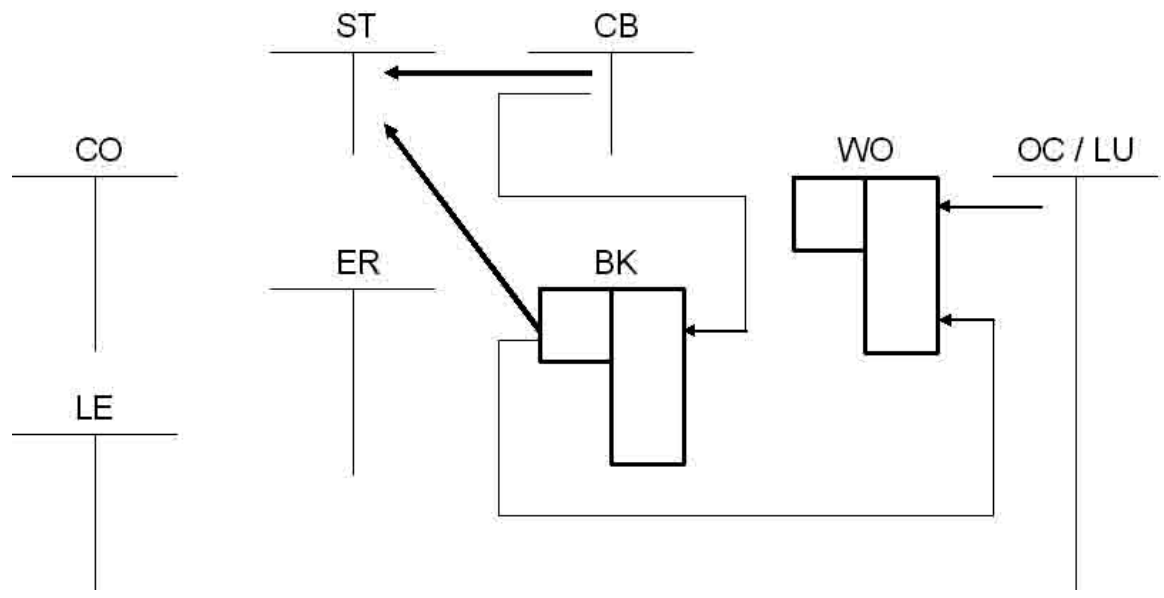
When Boris Yeltsin held his speech before the Duma in I99I, dissolving and even forbidding the Communist Party of the Soviet Union, he broke the backbone of the "vanguard mode of production « (Lebowitz 2000) without putting a functioning alternative into place. The economy crashed because not even for simple reproduction the necessary conditions were guaranteed - let alone for growth. It took many years before recuperation set in, assisted by rising oil and gas prices. Another type of Russian trouvaille symbiosis between capitalist market structures and authoritarian rule has since developed - whose analysis lies beyond the confines of this article.

\section{Summary: Intermediation Matters}

The puzzle of the micro-economics of Chinese growth can be approached, if not solved by asking for the institutions and mechanisms which guarantee the obviously high coherence and dynamism of economic decisions. Schumpeter had laid the foundations of the monetary theories of development in the pre-World War I period with its fabulous dynamism. His diagnosis of the social division of labour between unternehmer, bankier and wirt, with the state as facilitator and night-watchman securing the property rights of the individuals in the capitalist mode of production, can be taken as the basic model to be modified according to the circumstances in contemporary China. Analogous to Schumpeter's bank loan, created ex nibilo between entrepreneur (ER) and bank (BK), it is the command and later the order to finance via the banks, that the party secretary of the all-powerful CCP intermediates the transfer of resources between the status-quo WO and ER - equally ex nibilo, because he himself does not own the resources nor does he rely on voluntary "savings" from the side of WO. What he needs, however, is confidence in his ability to remunerate, one way or the other, not only the party secretary, but also the WO and its constituency of managers, owners, members, and other creditors (OC). When he cannot deliver, a crash in nihil might loom. Since a single party secretary is never able to come up with the necessary variety of goods and services to satisfy those requirements, he needs "refinance from his party comrades on all levels, who, in turn, draw on connections (拉关系 lā guānxi) on these claims in the cases of their own needs. Confidence beyond personal relations, with the party as quasi-clergy in a secularised, quasi-religious »developmentalist « state, turns out to be the clue for understanding the dynamism of recent Chinese growth. Guannxi is thus the magic word for trust, confidence, reliability, righteousness, mutual benefit and cosmic order, and it seems to be the magic thing in the contemporary Chinese economy.

In manuals on how to do business in contemporary China, the term guannxi is often explained and used, but seldom its institutionalised, constitutive character for the working of the whole economic system is identified and described, as we have tried here. In contrast to the Russian experience suffice it to stress the point $e$ contrario that coherence is crucial for every economy, which can be achieved through various institutional arrangements and regimes. And in order to grow beyond the stationary state of a more or less coherent equi- 
librium, Schumpeter is right to stress that institutionalised intermediation (IN) between WO and ER is decisive, when the entrepreneur can count on profits based on innovations (see figure Io). Unfortunately, his "creative destruction" is not always balanced in favour of creation, but can have a very destructive social and ecological bias, as China shows as well as all the other countries with economic growth. And Weber is also right in emphasising that some kind of religious "spirit« is essential for accumulation and that the theological foundations of these blessings can be rather different from the lessons and prescriptions their epigones are drawing from the »holy«scripts, be it the Lúnyı (論語, Analects of Confucius), the Bible, or the Communist Manifesto.

Figure Io: Intermediation Matters - Institutionalised Secondary Distribution of Capital

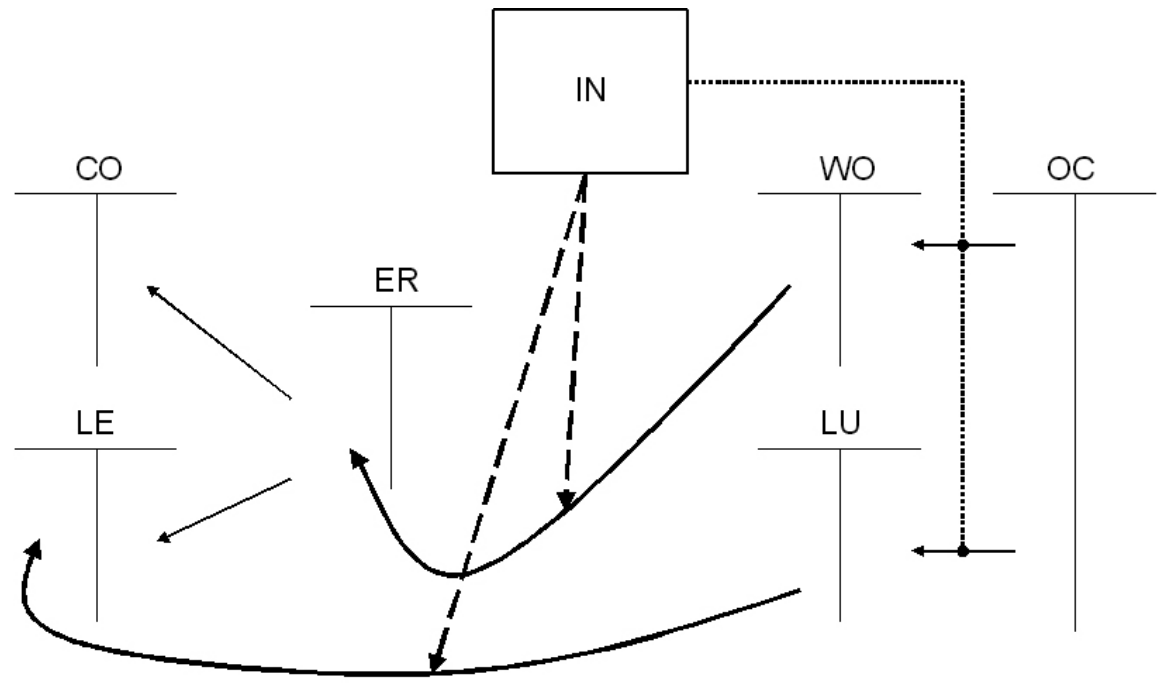

Within the mode of production approach to the theory of economic growth and development, the "guanxxi economy" of contemporary China occupies a rather unique position. Real socialism with public ownership of the means of production only seems to grow with Stalinist or Maoist oppression and campaigning, or it remains on the stage of Marx's "simple reproduction«. In the capitalist mode, money sets the stage, and the interplay between private creditors and debtors is bundled into a coherent, dynamic whole by the central bank in the economic sphere and by more or less democratic institutions in the political arena. Combining the reproductive, care-taking traits of socialism with the entrepreneurial dynamism of private property through the Communist Party guaranteeing coherence makes an ingenious institutional set-up.

With a trend of gradually channelling the directives through banks, the system could become more and more compatible with capitalist market structures, and with asset markets and rule-of-law instead of visible-hand procedures in public administration, it could even turn into a democratic political system with various freely elected political parties (PP) for 
a sovereign legislature (LG), an executive (EX), a legal authority (LA), a police force (PO) guaranteeing property rights, and an independent judiciary (JU), as a possible positive vision for the future (see figure II).

Figure II: Positive Vision - Economic Development and Democratic Welfare State

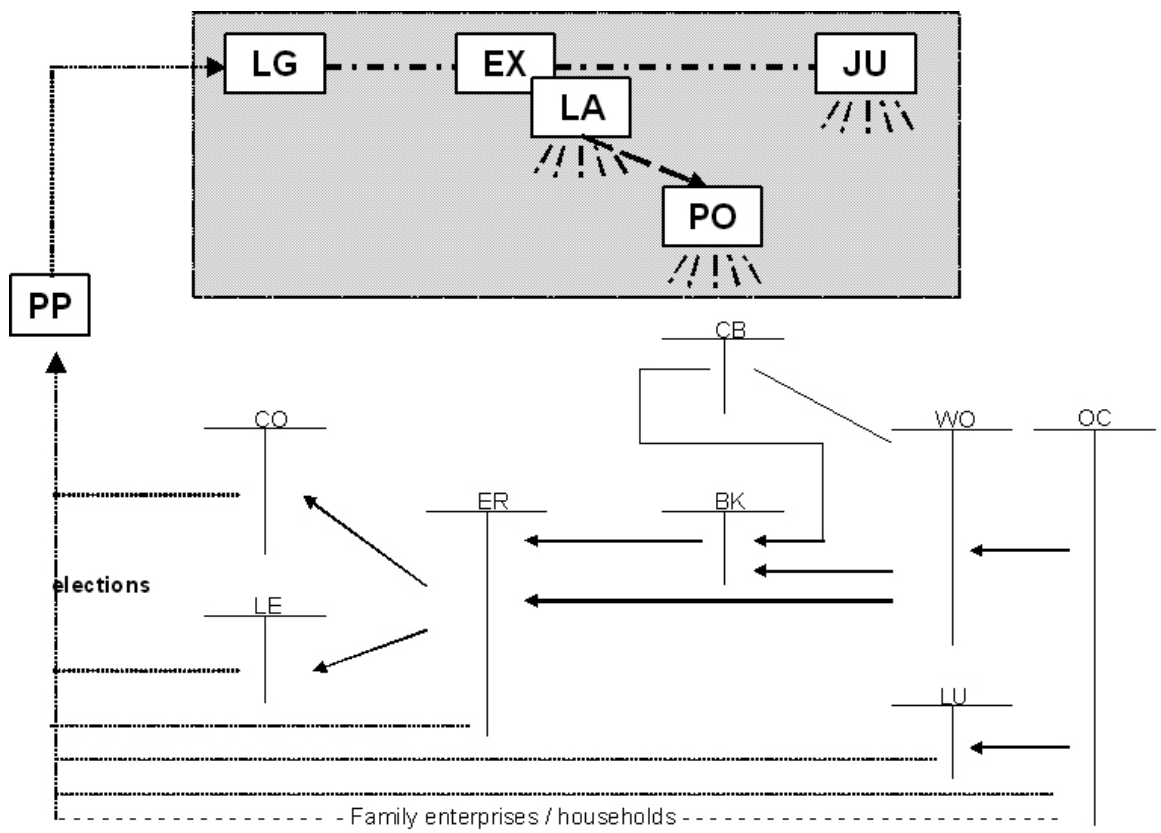

However, our argument should not be interpreted as a normative model, but as an analytical tool. Nor should any kind of teleology or determinism be projected into it. Capitalist entrepreneurs are not necessarily liberal democrats pressing for a multi-party system, free media, an independent judiciary, human rights, etc., nor does the »vanguard " party secretary give necessarily way to the democratic politician, and the OCs, let alone nature, are not automatically »taken care of «. Ours is an evolutionary approach, with an open future, and one with probably still many astonishing trouvailles on its long march.

\section{References}

Bagehot, Walter (1873/1999): Lombard Street. A Description of the Money Market, London: John Whiley \& Sons

Bao, Shixiang/Lao, An (1992): The Analects of Confucius: A Chinese-English Bilingual Edition, Jinan: Shandong Friendship Press

Chen, Guidi / Wu, Chuntao (2004): Zur Lage der chinesischen Bauern - eine Reportage, Frankfurt am Main: Zweitausendeins, 2006. The original Chinese: Zhōngguó nóngmín diàochá 中国农民调查, Beijing: Renmin chubanshe, 2004 
Davies, Howard/Leung, Thomas K. P./Luk, Sherriff T. K. / Wong, Yiu-hing (1995): The Benefits of "Guanxi« - The Value of Relationships in Developing the Chinese Market, in: Industrial Marketing Management, Vol. 24, No.3, pp. 207-2I4

Easterly, William (1999): The Ghost of Financing Gap: Testing the Growth Models of the International Financial Institutions, in: Journal of Development Economics, Vol. 6o, No. 2, pp. $423-438$

Easterly, William (2002): The Elusive Quest for Growth. Economists' Adventures and Misadventures in the Tropics, Cambridge, Mass./London: MIT Press

Friedman, Milton (1992): Money Mischief, New York: Harcourt Brace Jovanovich Heilmann, Sebastian (2002): Das politische System der Volksrepublik China, Wiesbaden Heilmann, Sebastian (2004): Das politische System der Volksrepublik China, Wiesbaden Herr, Hansjörg (2002): Das Finanzsystem in der VR China, in: Herr, Hansjörg/Sommer, Albrecht/He, Zerong (eds.), Nachholende Entwicklung in China: Geldpolitik und Restrukturierung, Berlin, Series: fhw-Forschung, No. 40/4I, pp. 2I-5I

Holbig, Heike (2005): „Wissenschaftliches Entwicklungskonzept», „Harmonische Gesellschaft « und »Eigenständige Innovation«: Neue parteipolitische Prioritäten unter Hu Jintao, in: China aktuell, Vol.34, No. 6, pp. I3-19

Huang, Guangguo (1988): Rújiā sīxiǎng yǔ Dōngyà xiàndàihuà 儒家思想與東亞現代化 (Confucianism and the Modernisation of East Asia), Taipei: Jùliú túshū gōngsī

Huang, Guangguo (1990): Rénqíng yǔ miànzi: Zhōngguórén de quánlì yóu xì人情與面子: 中國人的權力遊戲 (Humaneness and Face: Power Games of the Chinese), in: Yang, Guofu/Li, Yiyuan/Wen, Chongyi et al. (eds.), Xiàndàihuà yǔ Zhōngguóhuà lùnjí 現代化與中國化論集 (Anthology for Modernisation and Sinisation); Zhōngguórén cóngshū 中國人叢書, No.9, Taipei: Guìguān túshū gōngsī chūbǎn, pp. 125-I54

Joffe, Gideon (2003): Entstehung und Entwicklung des Unternehmertums in der VR China und sein Einfluss auf Transformation und Demokratisierung, Lohmar/Cologne

Kipnis, Andrew B. (1997): Producing Guanxi: Sentiment, Self, and Subculture in a North China Village, London: Duke University Press

Kline III, Thornton C. / Ivanhoe, Philip J. (eds.) (2000): Virtue, Nature, and Moral Agency in the Xunzi, Indianapolis: Hackett Publishing Company

Lau, Kin Chi (2006): Unzeitgemäße Betrachtungen über Modernisierung in China, in: Peripherie - Zeitschrift für Politik und Ökonomie in der Dritten Welt, Vol. 26, No. IO3, pp. $255-290$

Lebowitz, Michael A. (2000): Kornai and the Vanguard Mode of Production, in: Cambridge Journal of Economics, Vol.24, No.3, pp. 377-392

Luo, Yadong (2000): Guanxi and Business, Asia-Pacific Business Series I, Singapore: World Scientific

McKinnon, Ronald I. (1973): Money and Capital in Economic Development, Washington: Brookings

Moritz, Ralf (1989): Konfuzius: Gespräche (Lunyu), translation from Chinese, Cologne

Nitsch, Manfred (1999): Vom Nutzen des monetär-keynesianischen Ansatzes für Entwicklungstheorie und -politik, in: Schubert, Renate (ed.), Neue Wachstums- und 
Außenhandelstheorie. Implikationen für die Entwicklungstheorie und -politik, Berlin, pp. $183-2 \mathrm{I} 4$

Nitsch, Manfred (2002): Strukturelle Heterogenität in Lateinamerika und Osteuropa. Vom Nutzen des Produktionsweisen-Ansatzes für die Analyse von Akkumulation, (Unter)Entwicklung und Transformation sowie für den Aufbau von basisorientierten Finanzinstitutionen, in: Schorkowitz, Dittmar (ed.), Transition - Erosion - Reaktion. Zehn Jahre Transformation in Osteuropa, Frankfurt on the Main, pp. 9I-I29

Oi, Jean C. (1999): Rural China Takes Off. Institutional Foundations of Economic Reform, Berkeley: University of California Press

Porcelluzzi, Antonella Anna (2005): Bagehot and the Open Money Supply Approach, doctoral dissertation, Free University Berlin, URL: www.diss.fu-berlin.de/2005/220

Priewe, Jan (2005): Chinas rätselhaftes Wachstum, in: Intervention. Journal of Economics, Vol. 2, No. 2, pp. 2I-32

Rosemont, Henry Jr. (197I/200o): State and Society in the Hsün Tzu: A Philosophical Commentary. Monumenta Serica 29, No. 38. Reprint in: Kline III, Thornton C./Ivanhoe, Philip J. (eds.) (2000), Virtue, Nature, and Moral Agency in the Xunzi, Indianapolis: Hackett Publishing Company, pp. I-38

Schumpeter, Joseph A. (I9I2/I934): Theorie der wirtschaftlichen Entwicklung: Eine Untersuchung über Unternehmergewinn, Kapital, Kredit, Zins und den Konjunkturzyklus, Leipzig. English translation: The Theory of Economic Development: An Inquiry into Profits, Capital, Interest, and the Business Cycle, Cambridge, Mass: Harvard University Press, 1934

Shaw, Edward S. (1973): Financial Deepening in Economic Development, New York: Oxford University Press

Shirk, Susan L. (1992): The Chinese Political System and the Political Strategy of Economic Reform, in: Lieberthal, Kenneth G. / Lampton, David M. (eds.), Bureaucracy, Politics, and Decision Making in Post-Mao China, Berkeley: University of California Press, pp. 59-91

Watson, Burton (1963): Hsün Tzu - Basic Writings, New York: Columbia University Press

Weber, Max (1905/1965): Die protestantische Ethik und der Geist des Kapitalismus, in: Weber, Max, Die protestantische Ethik. Eine Aufsatzsammlung, München/Hamburg, English translation: The Protestant Ethic and the Spirit of Capitalism, New York: Scribner, 1958

Weber, Max (1925/1976): Wirtschaft und Gesellschaft - Grundriss der verstehenden Soziologie, Tübingen

Wibowo, Ignatius (2000): The Current State of the Communist Party in the Countryside, East Asian Institute (EAI), Contemporary China Series, No. 25, Singapore: World Scientific Publishing and Singapore University Press

Yang, Mayfair Mei-hui (1994): Gifts, Favors and Banquets - The Art of Social Relationship in China, New York: Cornell University Press

Zhou, Zhenghuan (2005): Liberal Rights and Political Culture - Envisioning Democracy in China, New York/London: Routledge 